\title{
Martinborough's Wine Tourists and the Metro-Rural Idyll
}

PETER HOWLAND

I definitely come to Martinborough to get away from the hassles of life in Wellington. I have a stressful job in town and when we drive over the hill I see the whole of the Wairarapa open up before me and I feel my whole body relax. One of the first things I do when we arrive is hop on the swing in the backyard and just swing. It's sort of a ritual of getting in touch with my inner child, leaving behind all the stress (Martinborough holiday home owner, mid-40s, female, Wellington resident).

Martinborough, a small boutique 'wine village' approximately one hour's drive from Wellington, the capital city of New Zealand, is a popular holiday destination for the capital's affluent, tertiary-educated and urbane middle classes. ${ }^{2 / 3}$ Many of the tourists 1 studied, aside from desiring an in-situ 'vineyard experience' and a relaxing 'time out' from city life, were also drawn by romanticised notions of rural life, by the prospects of consuming Martinborough's renowned wines and other cosmopolitan offerings (e.g. luxury accommodation), and by the likelihood of enjoying 'quality time' with friends and lovers. Martinborough's holidaymakers thus aspired to endeavours that were popularly associated with both the rural and the metropolitan. In some respects, the tourists' desires resonate back to the original Arcadia, the prototypical rural idyll believed to be the foundation of agriculture and domesticated animals, art, music, literature and collaborative community, and a necessary precursor to the evolution of Greek civilisation. ${ }^{4}$

Specifically, however, Martinborough's tourists desired experiences that, in part, emphasised core dispositions of middle-class distinction and reflexive individuality (i.e. self-referential/motivated personhood). ${ }^{5}$ A full discussion of this complex, mutually constitutive nexus is beyond the scope of this article. Instead I briefly discuss Martinborough's historical development as a 'wine village' and outline the entangled fundamentals of the tourists' rural and 'metro-rural'6 idylls, middle-class distinction and 'ideal reflexive individuality'? I also examine how specific aspects of the rural idyll - the picturesque and the biographised artisanship of rural production - respectively provided ideological endorsement for the tourists' urbane, ephemeral consumption of wine and for the individualised 'cult of the winemaker'. 


\section{The evolution of the Martinborough 'wine village'}

Martinborough is one of a few 'squire towns' (i.e. townships privately established by individuals) in New Zealand and was first envisaged in 1879 when the Honourable John Martin, a member of the Legislative Council of New Zealand, announced his plans to auction part of his newly-acquired 33,000 acre Huangarua station into 593 town sections (up to one acre in size) and 334 small farm blocks (ranging from 4.5 to 1100 acres).

The establishment of Martinborough represented the pinnacle of Martin's career in property development and his associated quest for elite social status. It was an act of monumental self-affirmation borne of Martin's 'country squire' aspirations, which undoubtedly had their foundations in the British Isles of his birth, and was thus a grounded statement 'of his success and proved to the sceptics that he had made it. ${ }^{3}$ In addition, by laying out the town centre of Martinborough in the shape of the Union Jack and in naming its central streets after places he had visited on his Grand Tour in 1875 (New York, Cologne and elsewhere) Martin also signified, and embedded within the South Wairarapa landscape, his allegiance to and positive experiences of British imperialism in nineteenth-century New Zealand.

Throughout the twentieth century Martinborough largely fulfilled Martin's predictions that it would service the burgeoning agricultural population living in an area now governed by the South Wairarapa District Council, which at 2484 square kilometres is the largest district council region in New Zealand. ${ }^{9}$ Martinborough's fortunes mirrored those of the agricultural economy, experiencing boom times in the 1950s due to the high wool prices of the Korean War and a marked decline following the closure of international markets due to the establishment of the European Union in 1973. Indeed, long-time residents described the Martinborough of this time as a 'ghost town'. This, together with the threat of the removal of government farming subsidies in the mid-1980s, prompted local farmers to sell land and/or diversify production - changes that directly resulted in the development of local wine and tourism industries.

The first vineyards - Dry River, Ata Rangi, Waihenga Vineyard and Chifney - were planted in 1979-1980 on approximately 46 acres (18.6 hectares) of farmland that was in poor condition and principally used for temporarily holding stock to be auctioned or transported elsewhere. According to one long-time resident: 'The land where most of vineyards are now was rubbish. Very dry and stony. No grass in summer, only weeds. In fact I could have bought 44 acres there in the 1970s for about $\$ 40,000 \ldots$ Wish I had now' (Male, retired, late 60s). In 2002 Te Kairanga vineyard bought one of the last remaining bare blocks of land on the eastern end of Martinborough's famed stony terrace - 11.25 acres on Martin Road - for a record $\$ 40,000$ an acre. ${ }^{10}$ 
By 2006 there were 39 local vineyards registered as members of New Zealand Winegrowers with more than 809 hectares of plantings. Many Martinborough vineyards are boutique enterprises and are classified as Category I (less than 200,000 litres of grape wine sales). Only Craggy Range, Palliser Estate and Te Kairanga are listed as Category II (between 200,000 and $2 \mathrm{~m}$ litres) and none are classified as Category III (more than $2 \mathrm{~m}$ litres). Pinot Noir is the principal variety grown in Martinborough, and the Wairarapa region has the third largest Pinot Noir plantings (435ha) in New Zealand, behind Central Otago (975ha) and Marlborough (1715ha). In 2006 Pinot Noir was the second most popular grape variety $(18 \%)$ grown in New Zealand. Sauvignon Blanc was the most popular (40\%) and Chardonnay the third (17\%)." Martinborough wines are typically marketed as highquality, and local Pinot Noirs retail at the high end of the market in New Zealand. For example, Ata Rangi and Martinborough Vineyard Pinot Noirs retailed at $\$ 60 \mathrm{NZ}$ a $750 \mathrm{ml}$ bottle in 2007 . This compares with lesser Pinot Noirs from areas such Marlborough and Waipara which typically retailed at $\$ 27-\$ 30 \mathrm{NZ}$.

The development of the wine industry prompted the evolution of a tourism industry, with visitor numbers for the Wairarapa and Martinborough increasing dramatically over time. For example, in July 1996 a total of 8477 guest nights (7290 domestic; 1190 international) were recorded from 32 Wairarapa accommodation providers with a combined 845 stay units and 120 full-time employees. ${ }^{12}$ By July 2004 a similar survey recorded 58 accommodation providers provisioning 12,119 guest nights (10,625 domestic; 1493 international), 1270 stay units (up 33.5\%) and 260 (up 116.7\%) full-time employees. ${ }^{13}$

Martinborough's transformation is also evident in that the only guest accommodation of any consequence in the mid-1970s were the Martinborough Hotel and Club Hotel, ${ }^{14}$ both in marked states of disrepair, and a few private holiday homes. However, in 2005 the GoWairarapa tourism website recorded for Martinborough: six motel/hotel/lodge establishments; 90 self-contained accommodation providers, which mostly operate from former residential properties; nine bed and breakfast outfits, which provide accommodation in occupied domestic residences; and two backpackers or budget accommodation providers. ${ }^{15}$

In fact, self-contained and homestay tourist accommodation utilised nearly 100 , or approximately $18 \%$, of the 561 Martinborough residences recorded in the 2001 New Zealand census. Furthermore, since 1991 Martinborough's resident population has decreased from 1580 people in 586 households to 1356 individuals in 561 households in 2001, a net decrease of 224 individuals $(16.5 \%)$ and $25(4.2 \%)$ households. ${ }^{16}$ During a similar period -1990 to 2003 - the roll of the Martinborough Primary School has dropped from 
323 to 173 , a net decrease of 150 students or $46 \% . .^{17}$ Yet between 1997 and mid-October 2004, the South Wairarapa District Council approved a total of 165 building permits for new dwellings in Martinborough, and some 104 dwellings were relocated into the township and nearby area. ${ }^{18}$ Thus as Martinborough has transformed into a tourism destination, the resident community has decreased, while the episodic population - of tourists and holiday homeowners - has conversely increased.

\section{The touristic idyll}

Many tourists, in collusion with tourism promoters, winemakers and local retailers, readily associated Martinborough with the mythology of an enduring, vernacular rural idyll that celebrated picturesque, 'clean-green' and productive landscapes; biographised (i.e. named and socially known) pastoral producers; intimate, cohesive farming families and rural communities; and a 'Golden Past' that was apparent in the touristic adulation of colonial cottages, villas and homesteads, historic townscapes and 'old, rustic' farm buildings such as corrugated iron implement sheds. Indeed, many aspects of the tourists' rural idyll, especially harmonious pastoral communities and the relaxed, 'slow paced' lifestyle, were ideologically embedded in the historicity of 'olden times' or 'in the past'. Like many 'invented traditions', ${ }^{19}$ the tourists' rural idyll was historically ambiguous or 'genealogical', ${ }^{20}$ focused primarily on generalised epochs (e.g. the colonial past) rather than specific moments or events in history. A genealogical rural idyll effectively acts as a narrative of 'cosmological authentication', ${ }^{21}$ is enabled to carry a variety of potentially contradictory ideological and symbolic loads, and is able to be readily altered to reflect contemporary aspirations.

Tourists often purposefully emulated aspects of the vernacular rural idyll - for example, by waving to or saying 'hello' to strangers whilst walking between vineyards; by pursuing personalised connections with winemakers and homestay operators; and by desiring to holiday in 'a colonial cottage with a fireplace and bath big enough for two'.22 For most, however, a retreat to Martinborough was clearly an episodic, temporary affair rather than a wholesale commitment to a romanticised rural lifestyle. Despite spontaneously referencing the rural idyll in conversations and in response to direct questioning, many renounced the rural idyll in practice. Many travelled without their dependent children, ${ }^{23}$ preferring instead leisured 'quality time' with friends and lovers, thereby effectively flouting the familial tenet of the rural idyll. As one tourist explained: 'You can choose to have children, but you can't choose the children you have - and I definitely need some time-out from my kids' (Male, mid-40s). Furthermore, although many tourists sought to biographise the industrious efforts of Martinborough's winemakers, in part to transcend the contractual anonymity and alienability that is characteristic 
of commodity exchange in the metropolis, they were nevertheless chiefly interested in narratives that exemplified the heroic, reflexive artisanship or folkcraft of locally-manufactured urbane commodities. Accordingly, many regarded the agricultural production of dairy and sheep farms as comparatively unattractive and uninspiring. Tourists' complaints about earlymorning topdressing planes, the noisy, smelly movement of livestock and loud tractors operating on nearby farms were reasonably common. Many likewise railed against the more obvious industrial aspects of winemaking, especially the use of helicopters to dissipate early-morning spring frosts and 'cannons' to frighten birds away from ripening grapes. Indeed, one homestay operator was found by the Wellington Disputes Tribunal to have falsely advertised their cottage as 'peaceful' and thus to have breached contract with a guest who was awoken by a bird-scaring gun on a nearby vineyard at $7 \mathrm{am}$ in the morning. ${ }^{24}$

Nonetheless, many idyllically-inclined tourists turned a deaf ear to the various socio-economic tribulations of small-scale, family farms, the comparatively under-resourced, decentralised character of Martinborough's infrastructure and to the low wages, lack of employment opportunities and geographical isolation of its rural inhabitants. ${ }^{25}$ Furthermore, many complained about the rusticity of Martinborough. Some derided the 'unsophisticated service' they had received in Martinborough's restaurants and cafés, while others referred to resident locals as 'country bumpkins': 'Some of [the] waitresses simply have no idea. It [is] like they just stepped off the farm. I mean when you are paying through the nose for a meal in a good restaurant you expect top quality service' (Tourist, male, mid-40s, manager, Wellington resident). Many also complained about the 'high cost' of wine, deli foodstuffs and café meals, clearly indicating that as Martinborough was regarded as 'a rural place', its shop rentals, labour costs and so on should not only be cheaper than in the city, but the gullibility of its small town 'hicks' ought to result in urbane consumption at bargain prices.

\section{The urbane idyll}

Positive images of rural life often provide ways to talk about improving the city ... not as an alternative to the city, but as a moral image to inspire or discipline urban behaviour. The ideal country is the place urbanites visit, not the place where poor people eke out a living. Urban dwellers who are free from the stigma of rusticity can wax eloquently about the countryside or embrace it as a retreat without undermining their own cultural superiority. ${ }^{26}$

Tourists typically fixed a selective romantic gaze ${ }^{27}$ upon Martinborough to produce a rural idyll that not only provided a picturesque, socially benign setting, but that also expressly facilitated and endorsed their metropolitan- 
based ideals of individualism, leisured sociality and urbane consumption. Martinborough was thus cast and staged as a metro-rural idyll - an enchanted, ${ }^{28}$ performative field of action that resonated with the metropolitan habitus $^{29}$ of the wine tourists and especially their ideals of individualism and urbanity or cosmopolitanism. ${ }^{30}$ The vernacular rural idyll was thus effectively deployed to provide a moral foundation and corroborating setting that validated the tourists' nexus of social distinction and ideal reflexive individuality - an entanglement that was manifested in their narratives, activities and interactions pursued in Martinborough's vineyards, cafés, restaurants and other conspicuous settings.

The pursuit of middle-class distinction and associated status hierarchies was especially apparent in the tourists' leisured, discretionary deployment and acknowledgement of varied economic, social and cultural capitals:

As the objective distance from necessity grows, life-style increasingly becomes the product of what Weber calls a 'stylization of life', a systematic commitment which orients and organizes the most diverse practices - the choice of a vintage or a cheese or the decoration of a holiday home in the country. This affirmation of power over a dominated necessity always implies a claim to a legitimate superiority over those who, because they cannot assert the same contempt for contingencies in gratuitous luxury and conspicuous consumption, remain dominated by ordinary interests and urgencies. ${ }^{31}$

Thus conspicuous displays of wealth - especially expenditure on, and the leisured consumption of, Martinborough's fine wines, gourmet foodstuffs, luxury holiday accommodation and expensive cars elicited spontaneous adulatory comments from tourists. Even the appearance of a Platinum American Express card caused some tourists and many Martinborough retailers to virtually purr in appreciation. In addition, individuals who could boast of a friendship with a renowned Martinborough winemaker, indeed even those who could simply tell of a personalised winemaker encounter, were typically accorded high status by fellow holidaymakers and their wine assessments were often deferred to. Similarly, the appearance of notable individuals, such as Adrien Brody, Oscar winner and King Kong star, or local VIPs such as Roderick Deane, the former Chairman of Telecom, provoked excited adulatory chatter amongst tourists and tourism operators alike - with those who told of personal celebrity interactions excitedly listened to and feted. The cultural capitals of wine connoisseurship, gourmet sophistication and aesthetic appreciation of Martinborough's historic and neo-modernist architecture were also regarded as markers of middle-class distinction. The social distinction accorded individuals and associated status hierarchies are context or field-of-action specific. ${ }^{32}$ Thus in wine tasting contexts, 
connoisseurship was most highly valued, whereas access to corporate tickets for the highly popular and over-subscribed Toast Martinborough Wine \& Food Festival was heavily dependent on individuals' social networks and connections ${ }^{33}$ Furthermore, gradations or variances in any of these capitals provided the mechanisms for negotiating status hierarchies.

The social hierarchies constructed via nuances in economic and cultural capitals were, however, significantly mitigated via the expansive economics of credit cards, singular forms of commodity consumption (e.g. wine purchased by the glass) and by the 'democratisation' of wine connoisseurship (e.g. readily accessible tasting notes, quality rating systems and tiered production), of which many tourists availed themselves. ${ }^{34}$ Such mechanisms also enabled tourists to readily pursue another key marker of middle-class distinction - the desire for and experience of reflexive individualism.

\section{Reflexive metro-rurality}

Reflexive individuality was especially manifest in tourists' conspicuous and personalised enactments of consumer choice, including instances where holidaymakers 'treated' or gifted themselves ${ }^{35}$ indulgent items such as expensive bottles of wine, designer clothing or indeed a Martinborough holiday in its entirety. It was also readily apparent in tourists' expressed personal tastes in wine, which were socially validated by wine shop hosts and other tourists; in their intentionally selected, self-affirming choices of friends and lovers - that is, of other adult, competent reflexive individuals - as travelling companions, ${ }^{36}$ in their biographisation of wine production, purchase and consumption; and in their touristic conversations that were persistently punctuated with reflexive utterances such as 'I think . . ', 'I said to . . ., 'I feel . . ,', 'I love . .,', 'I hate . . . Although such utterances and other reflexive practices are not exclusive to the field of action represented by Martinborough's tourism, I argue they take on an extraordinary dimension in such an enchanted, leisured and episodic locale - this metro-rural idyll - and as such, significantly reflect the tourists' desire for, and pursuit of, an exalted, praiseworthy self. ${ }^{37}$

This desire arises from the pervasive institutionalisation of individualism in industrial/post-industrial societies: 'Institutionalized individualism ... [is] the social structure of second modern society itself.' ${ }^{38}$ Institutionalised individualism is evident in the structural compulsion of individuals to personally negotiate their way through a bevy of social institutions, ranging from educational qualifications, income/wealth attainment through to welfare support: 'For modern social advantages one has to do something, to make an active effort. One has to win, know how to assert one-self in the competition for limited resources - and not only once, but day after day. ${ }^{39}$ Furthermore, knowledge - scientific, religious, common sense - in individualising societies 
characteristically takes the form of hypothesis and is continuously open to critical revision. Therefore information and authority are typically perceived as multiple, divergent and inherently contestable. Accordingly, there appears to be a persistent expansion of alternative subject positionings and viable life-trajectories - all of which hegemonically induce a desire for reflexive or self-referential individuality: 'The human being becomes . . . a choice among possibilities, homo optionis. ${ }^{90}$

\section{The ideal reflexive individual}

The institutionalisation of individualism is also reflected in the emergence of a 'reflexive habitus. ${ }^{241}$ Bourdieu argues that differentiated social practices emerge from different habitus. Habitus is an enculturated 'system of cognitive and motivating structures ${ }^{92}$ that produces a subconscious framework of dispositions and associated capitals (economic, social, cultural and symbolic) that individuals acquire from, and dynamically deploy within, the various fields of action into which they are born, are educated, construct and/ or experience throughout their lifetimes. In Western societies formative habitus is especially apparent in individuals' family origins and educational backgrounds. Habitus is not determinative, but instead generates classificatory schemes that guide individuals and groups in constructing notions of 'what is good and what is bad . . . what is distinguished and what is vulgar'. ${ }^{43}$ Thus in Bourdieu's famous formula '[(habitus) (capital)] + field = practice' ${ }^{44}$

$I$ argue that reflexive habitus, which likewise is especially evident in individuals' educational experiences ${ }^{45}$ chiefly generates a system of 'durable, transposable ${ }^{\prime 46}$ and, most importantly, idealised dispositions that evolve within, yet underscore, other habitus (e.g. ethnic ${ }^{47}$ religious $^{48}$ etc). Indeed, the reflexive habitus of Martinborough's tourists was, in part, reflected in an ethos of individual seekership, self-awareness and meaning/narrative authorship. This ethos was generated within their entangled praxis of tertiary education, knowledge-centric occupations, vocational/geographical mobility, economic affluence and the hyper-referentiality of the internet and television that is characteristically experienced by the middle classes.

The ideal dispositions of reflexive individuality are especially focused on autonomy of emotion, thought, action and interaction. In other words, an ideal reflexive individual is regarded as the 'architect of their own destiny'. ${ }^{49}$ Accordingly, reflexive individuals seek to purposefully engage, and in many respects intentionally create, the various pathways of their life (e.g. occupation, life politics, social connectedness)..$^{50}$ Reflexive individuals also deliberately attempt to cultivate autobiographical or C.V. milestones and advancements. Unsurprisingly, the capacity to personally enact choice is widely considered a cornerstone of reflexive individuality, and a person's distinct configuration of lifestyle choices ideally casts them as a unique 
entity. Furthermore, as institutionalised individualism appreciably evolved in the crucible of eighteenth-century neo-romanticism and the associated cult of sensibility ${ }^{51}$ that marked the expansion of industrial capitalism and the social fluorescence of the middle classes, the ideal reflexive individual often pursued endeavours on the basis of personally affective 'feels good', 'feels right' criteria.

Embracing the aspirations and pursuing the ideals of reflexive individualism is, however, undoubtedly a precarious, perhaps even illusory, enterprise.$^{52}$ Firstly, the ideology of reflexive individualism hegemonically deflects critical attention away from the multitude of structural impediments (e.g. occupational 'glass ceilings') to individual success while simultaneously framing failures as personal: 'Your own life - your own failure. ${ }^{53}$ Moreover, as many are routinely thwarted in their pursuit of ideal reflexive individuality, they accordingly experience abiding frustration. This is reflected, in part, by tourists who expressed dissatisfaction with corporate or institutional anonymity, capricious friendships, unfulfilling marriages, ungrateful offspring and with various governmental/civic obligations or impositions (e.g. taxes and jury duty). In practice such factors clearly undermine and highlight the limitations of an individual's capacity to enact personal choices, let alone be autonomous.

Individuals are therefore drawn toward, and routinely celebrate, those areas of existence where they perceive ideal reflexive individuality is most likely to be optimised - for example, in the realms of educational and occupational advancement, life politics, and in various identity projects (e.g. sexual, ethnic and recreational - music, sports associations etc.). That Martinborough's tourists most obviously pursued ideal reflexive individuality in their leisured, conspicuous consumption of wine and holidays; via the self-affirming sociality of friends and lovers; and within their reflexive, autobiographical narratives is somewhat predictable. Consumption in all its guises, but especially in terms of the conspicuous consumption of luxuries, of big-ticket items such as houses and cars, and of leisured, pleasure-seeking indulgences, has long been recognised as synchronised displays of social distinction and self-assembled identifications. ${ }^{54}$ Likewise the contraceptive freedom from sexual reproduction, together with the demise (moral and in practice) of heterosexual nuclear families and the emergence of a variety of sanctioned intimate relationships based on 'plastic sexuality', ${ }^{55}$ has been credited with thrusting 'reflexive sociality ${ }^{56}$ to the forefront of interpersonal intimacy and care. Thus those forms of social connectedness that appear especially amenable to personal negotiation and intent - most notably friendships and 'romantic' attachments - are accorded social significance in individualising societies. ${ }^{57}$ Lastly, many scholars suspect that individuals chiefly find reflexive solace, cohesion and adulation in the retrospective, 
anticipatory, justificatory and idealised narratives ${ }^{58}$ - essentially the 'tall tales' - that we all tell about ourselves. Clearly none of these endeavours are exclusively pursued within the confines of a Martinborough holiday. Yet within Martinborough's metro-rural idyll, such dispositions and allied endeavours are clearly (re)cast as extra-ordinary and as such are conspicuously pursued in the ideal. Thus the tourists' desire for picturesque, pristine rural landscapes endorses their ephemeral, middle-class consumption of wine, and the romanticised artisanship of rural production likewise sanctions the individualised cult of the winemaker.

\section{Picturesque Martinborough and ephemeral wines}

I love driving or walking around looking at all the vineyards ... everything's so tidy with hundred[s] and hundreds of rows of grapes, it's very pretty (Female tourist, early 40s, from Hamilton).

Many tourists customarily believed the various types of farms near or surrounding Martinborough - the sheep and dairy farms with 'large open, green fields', the 'pretty and neat' vineyards or 'relaxed, peaceful' olive groves - were 'more in tune with nature'. Tourists thus cast Martinborough's rurality as picturesque and 'clean, green', often contrasting this with the densely urbanised, polluted and fast-paced quality of their everyday city existence.

The tourists' picturesque aesthetic was also evident in advertising promotions, with Martinborough incorporated as part of an idyllic retreat rubric - a 'Capital Country Escape' ${ }^{59}$ - that encompassed the entire Wairarapa region:

Only 90 minutes drive from Wellington find yourself 'over the hill and a world away'. Essentially rural with 'off the beaten track' charm, Wairarapa offers a diverse experience for lovers of great wine, gourmet organically-grown food, astonishing wildlife and natural beauty. Rolling vineyards, acres of apple orchards, fields of lavender, olive groves, heritage museums and quaint historic towns combine to make this a great destination. ${ }^{60}$

Martinborough's winemakers were similarly attuned to the tourists' pastoral inclinations. For example, on the afternoon before the 1999 Toast Martinborough Wine \& Food Festival, ${ }^{61} I$, together with seven other vineyard workers, spent three hours - in effect 24 hours of one person's labour or three typical working days - deadheading two beds of Livingstone daisies so that only the most pristine remained to faultlessly greet the parched hordes expected the following day.

The tourists' picturesque aesthetic references an Arcadian stereotype centred on a pristine, benign and physically attractive view of the natural 
world. For example, members of a vineyard tour group I accompanied, approximately 12 or so, were so alarmed by the sight of a dead lamb lying in a paddock that they refused to taste the wine and food offered at a nearby vineyard for fear of 'contamination'. I asked one individual why they were so shocked, especially as any farm has both dead and live stock at some point, and she replied: 'That's not the point, it is simply bad marketing to have a dead lamb lying there along the driveway to the vineyard . . . it really put me off' (Wine tourist, female, mid-20s). Such aesthetic sensibilities are typical of many university-educated individuals ${ }^{62}$ and are perhaps also significantly accentuated by commodification. These aesthetics are not merely form or surface-orientated, however, but also reflect the individual attainment of valued knowledge, emotions and moralities. Thus the tourists' bucolic framing of Martinborough's agriculture, in collusion with their leisurely, holiday dispositions, clearly denoted their middle-class 'distance from necessity' - especially from the often-harsh realities of rural production and correspondingly from the tourists' everyday metropolitan responsibilities such as employment and domestic duties.

The tourists' picturesque sensibilities arguably reference the fifteenthcentury Renaissance development of landscape painting in Northern Italy ${ }^{63}$ in which the real work, hardships and society of rural peasants were expunged from the countryside, thereby pictorially and ideologically transforming the pastoral into a space for aristocratic theatre, entertainment and pleasant scenery. ${ }^{64}$ The picturesque movement that emerged in eighteenth-century Europe clearly cited this landscape imaginary, and in England many country estates were (re)developed to highlight "pure landscape ... [that required] whole hills to be levelled (or raised), lakes dug and mountains of manure carted to the estate ${ }^{\prime 5}$ Closely aligned with neo-romanticism as championed by Jean-Jacques Rousseau $(1712-1778)$ and situated within the rural idyll sensibilities of the time, the picturesque movement was likewise a reaction against industrialisation and a lament for the loss of 'authentic' human existence. The rapidly evolving tourism industry was also swept up in picturesque fervour, and areas such as the Lake District in England, with its quaint villages, serene lakes, rolling hills and charmingly unlettered people' ${ }^{66}$ inspired a plethora of guidebooks and accommodated armies of middle-class travellers equipped with Claude-glasses ${ }^{67}$ That such landscapes harboured poverty and deprivation was typically lost upon the urban travellers, and the rural peasantry were effectively cast as integral parts of the naturalistic environment, remnants of a lost Golden Age of virtuous simplicity and harmony. Notions of the picturesque, however, quickly merged with the similarly new-found eighteenth-century appreciation of the sublime or wild and feral landscapes. Indeed, today, terms such picturesque, beautiful, romantic and sublime are virtually interchangeable. ${ }^{68}$ 
The eighteenth-century picturesque-cum-romantic gaze of the French and British middle classes ${ }^{69}$ significantly conflated literary knowledge and aesthetic sensibilities so that erudite references to Virgil, Wordsworth or Austen were symbolically embodied within landscapes. In contrast, however, Martinborough's tourists deployed a vernacular sensibility that especially favoured a productive rurality: 'It is wonderful to see how the vineyards have transformed Martinborough. There is a lot of employment and new businesses everywhere - and it's all because the vineyards turned previously useless farmland into something really special' (Tourist, male, mid-50s, business owner). This industrious perspective has its foundations amongst New Zealand's nineteenth-century European colonisers who regarded settlement foremost as a calculated, rational business proposition..$^{70}$ Nevertheless, in seeking to establish 'the Great Britain of the Pacific'71 settlers frequently drew upon yeomen-like notions of a pastoral, socially harmonious 'Better Britain ${ }^{72}$ and blended these with an ardent desire for a technologically, economically and politically progressive 'Greater Britain'?3

At a base level the tourists' collusive notions of the picturesque and the rural idyll reference contemporary naturalistic sensibilities, which also emerged within eighteenth-century neo-romanticism and which contend that phenomena deemed natural are inherently beneficial to humans and/or are morally worthwhile. ${ }^{74}$ Therefore a bevy of Martinborough endeavours - from vineyards and wine production through to tourists' wine purchases, personal tastes, choice of travelling companions, the urbanity of social distinction and the sociality of holidays - were effectively endorsed as morally "clean and green' and as more authentic and praiseworthy though the virtue of in-situ or touristic 'being there' engagement. Hence the extraordinariness assigned to the metro-rural idyll.

As noted, however, the tourists' adulation of naturalised, industrious rurality was particularly directed toward the production of urbane commodities such as wine. Indeed, many regarded locally-produced and New Zealand wines as consummately 'environmentally-friendly'. Few, however, critically enquired about winemaking practices, and thus most were unaware that the Australia New Zealand Food Standards Code endorses 32 additives that may be legally used in winemaking, including gum arabic, a range of acids (lactic, malic, fumaric etc.), fish isinglass (a protein obtained from fresh-water fish bladders), gelatine, bentonite clay, and milk or egg whites to remove impurities such as dead yeast. ${ }^{75}$ Furthermore, most vineyards use sulphur spray to control the spread of destructive bacteria on growing grapes.

Instead, most tourists had faith in the winemakers' integrity, with one dedicated vegan tourist stating she was 'unfussed' by the use of animal products in fining wine and firmly believed winemakers' assertions that 
there are no detectable traces in bottled wine: 'You have to draw the line somewhere'. Indeed, many tourists believed that Martinborough's winemakers were especially inclined to engage best practice as any damage to their reputations would be economically catastrophic for their boutique, 'familyrun' vineyards. Moreover, tourists often regarded practices such as handpicked or hand-plunged grapes as being especially environmentally sound. In this regard they referenced the artisanship or folkcraft romantically associated with the rural idyll and thus regarded minimal 'industrial' interventions as evidence of a benign, yet cultivated or refined, communion with nature.

The tourists' picturesque, rural idyll and naturalistic sensibilities also served to underscore and accentuate the innate capacity of wine to vary in taste according to seasons, vineyards, grape varietals, climate variations, the winemaking techniques employed and, in the best examples, cellaring over time. Since the seventeenth-century Burgundian development of vineyardand vintage-specific wines ${ }^{76}$ such variables have been especially influential in the perception and assignment of differential wine quality. The subsequent development of restaurants and wine bars, ${ }^{77}$ in combination with the associated evolution of singular sales (i.e. by the bottle or glass), eventually propelled conspicuous and appreciative or connoisseur-like consumption of wine toward being an indicator and stratifying mechanism of middle-class distinction: 'Good wine and the culture attached to it have become a symbol of middle-class lifestyle, and more so than food its consumption acts [as] a social marker or sign of belonging to a dominant social class. ${ }^{78}$

As noted Martinborough's tourists were sensitively attuned toward conspicuous expressions of social distinction, both in terms of signifying general middle-class status and in negotiating status hierarchies. The leisured, urbane and performative consumption of a Martinborough holiday was itself considered a denotative middle-class activity. With respect to wine consumption, social distinction was likewise constructed via the differential deployment of three principal capitals. Firstly, tourists with the economic capital to purchase expensive, top-quality wines were accorded high status, more so if they were perceived to do so on a regular basis. Second, individuals who demonstrated connoisseur-like appreciation (i.e. cultural capital) of fine wine were accorded even greater status. Lastly, high status was also attributed to those tourists who had formed personal or close relationships (i.e. social capital) with renowned Martinborough winemakers. Socially acknowledged possession of all three capitals routinely resulted in the ascription of the highest status.

Furthermore, wine's natural - yet socio-culturally acknowledged - variations effectively cast it as a commodity that routinely constructed and satisfied the middle-class quest for novelty or fashionable change. Middle-class consumerism also emerged in union with eighteenth-century 
neo-romanticism and the cult of sensibility, both of which laid the foundations for, and continue to inform, modern forms of hedonism or pleasureseeking as evident in contemporary forms of leisured consumption. All are characterised by an endless quest for novelty and assign primacy to individual emotive experiences and evaluations: 'Pleasure of ephemerality is at the heart of the disciplining of the modern consumer. ${ }^{79}$ Pleasurable ephemerality is effectively found in the tension between nostalgia for valued losses (real, imagined or anticipated) and fantasies of an idealised future. This establishes an 'aesthetic of ephemerality' ${ }^{80}$ and 'imagined nostalgia' as central disciplines of modern merchandising. Consumers are thus taught to "miss things that they have never lost . . . That is, they create experiences of duration, passage, and loss that rewrite the lived histories of individuals, families, ethnic groups, and classes ... [This] creates much deeper wants than simple envy, imitation, or greed could by themselves invite. ${ }^{82}$ The idealisation of commodity ephemerality, however, also reflects broader historical and social processes that normalise persistent change, uncertainty and risk-taking ${ }^{83}$ and that also inculcate strongly-held beliefs in a better, more progressive future. ${ }^{84}$ Indeed, a message displayed on the spare-wheel cover of a four-wheel drive vehicle owned by a Martinborough tourist neatly encapsulated this ethos: 'Success demands difference'.

In fact many tourists delighted in deploying a 'wandering drinker' 85 ethos, serendipitously sampling wines from diverse vineyards, produced by different winemakers or those made via distinct production techniques. Martinborough's winemakers were also aware of this wandering character: 'It's a constant battle to keep attracting customers. We all have our loyal group of customers, but the majority seem to like to try out new wines or different vineyards' (Martinborough winemaker). Interestingly, New World wine connoisseurship, which was particularly evident amongst Martinborough's appreciative wine drinkers and is routinely endorsed by prominent domestic wine critics such as Bob Campbell and Michael Cooper, likewise favoured experimentation and eclecticism in wine consumption. Bargain hunting and the quest to discover inexpensive, good quality and previously 'undiscovered' wines was also highly valued by many Martinborough tourists. ${ }^{86}$ Moreover, wine tourists eagerly awaited vintage releases, and some undertook annual pilgrimages to Martinborough to sample the newly released offerings: 'We visit Martinborough about the same time each year principally to check out what our favourite vineyards have to offer in terms of new wine ... we usually leave with several cases of wine' (Tourist, male, mid-50s, selfemployed business owner).

Labelling wine by the year of vintage clearly signifies that it is regarded as an ephemeral and nostalgic commodity. Vintage classifications simultaneously highlight a specific moment in time and its loss. Thus a particular vintage 
may never be replicated and the best one can hope is that the next vintage will be as good or even better. Wine is therefore a product in which the 'nostalgia for the present ${ }^{\text {'77 }}$ is widely perceived to be embedded in its very nature. Accordingly, changes in consumer fashions or tastes for wine are likewise deemed to be natural and authentic. In addition, given that the quantity of wine from a single vintage is always finite, scarcity or the permanent loss of specific wines is a ubiquitous possibility - thus possession of a rare, high-quality wine is likewise a bona fide denotation of high social status.

In a similar vein many tourists fondly discussed wines they had previously consumed and critically compared these with current vintages. Some lamented that they had drunk all their stock of a 'great' past vintage or that a lauded vintage had 'sold out'. Many others simply remembered enjoyable occasions whilst holidaying in Martinborough, such as picnicking at a vineyard or dining at a local restaurant, in which recollections or re-enactments of the wine consumed acted as a metonymic reminder of past 'good times'. Thus procuring wine, much like taking holiday photographs or collecting tourist souvenirs, was often a purposeful act of laying down 'future memories' ${ }^{, 8}$ and the wine's future consumption served as a pleasure-inducing, nostalgic prompt: 'Every time I open a bottle of Ata Rangi Sauvignon Blanc I remember the first time I visited the vineyard and first tasted this wine . . I can smell the grass and feel the sunshine, and of course I can remember who I was with and the picnic we enjoyed at the vineyard' (Female tourist, late 30 s, Wellington-based).

\section{Rural artisanship and the cult of the winemaker}

Dear . . . - a note to say how good it was to see you over the weekend. Especially wanted to say (hoping it won't sound "precious") that it was a memorable experience sitting at the long table dans la chambre noire ${ }^{89}$ with the master - bit of a magic moment for me and I know the others felt the same (Female, 'wine buff', mid-50s - emphasis mine).

The above note was sent to a Martinborough winemaker by a tourist shortly after a chance meeting at the Medici Café near the town square. Tourists frequently elevated local winemakers to the status of celebrities or wine gurus and some paid them pilgrimage-like homage. ${ }^{90}$ Wine commentators similarly adulated Martinborough's winemakers: 'Larry McKenna, the prince of pinot';' and 'He doesn't allow tastings at his vineyard, he doesn't enter shows, but some call him The Master. Dr Neil McCallum. ${ }^{92}$ Indeed, some tourists suggested that Martinborough's winemakers were exalted conduits between the essential nature of the area (with its soil types, climate etc.) and the constantly evolving science of winemaking: 'The winemakers I have 
met are clearly very passionate about what they do . . they are like artists, but with a scientific bent. I think winemaking is as much an art as it is a science' (Wine tourist, male, mid-30s). Winemakers were thus frequently cast as named and inspired artisans who passionately, yet methodically, interpreted, nurtured and refined the best of nature to produce quality wines that were consequently considered more as signature works of art than anonymously produced commodities. In fact tourists routinely delighted in 'hand-made' arts/crafts (e.g. designer clothing, pottery) or 'home-grown' rural products (e.g. fruits, cheeses, jams, preserves), thus reproducing an idyllic notion that rural producers are named, socially acknowledged producers and their products, even their sites of production (e.g. family farms), are intimately associated with their individual personalities: 'I love all the crafts and hand-made products. I also enjoy meeting the people who make these things ... I really envy their passion for what they are doing ... makes my own work in admin seem very dull by comparison' (Female tourist, mid-30s, Wellington resident).

Many tourists likewise regarded the winemaker's palate, production philosophies and personality as pivotal to the final taste and quality of Martinborough wines:

The winemaker makes all the difference. Say you have two vineyards next to each other - same soil, same climate - but different winemakers and you get very different wines. The winemaker's unique personality, their tastes, their techniques are one part of winemaking that can never be completely replicated (Tourist and self-confessed wine buff, male, mid-50s).

In this respect the tourists significantly reproduced the 'cult of the winemaker ${ }^{93}$ prevalent in New Zealand:

New Zealanders tend to worship the winemaker rather than the vineyard. This NEW WORLD phenomenon is in direct contrast to the French view of the primacy of TERROIR. ${ }^{94} \mathrm{~A}$ decade or two will no doubt reveal the ephemeral nature of the winemakers and permanence of geography, but until that time New Zealand winemakers will continue to be revered by an adoring domestic public. ${ }^{95}$

The tourists, however, also referenced another core attribute of their vernacular rural idyll, namely the celebration of farming families and rural communities. This ideal was often expressed in terms of idealised social cohesion, harmony and intimacy. Indeed, many tourists commented on how friendly the 'locals' were and how everyone appeared to know one another in a 'neighbourly sort of way'. Others said it was nice to see gangs of children playing in streets, around the town square and at the local swimming hole by the SH.53 bridge over Ruamahanga River on the main 
route into Martinborough. Many tourists held the view that Martinborough vineyards were mostly 'family-run' enterprises and, like the districts' other farms, had different generations 'living and working' together, which resulted in 'better families and better communities'. Tourists thus typically believed that rural places were inhabited by people who shared a wide range of life experiences (e.g. schooling, recreation, work) or who were empathetically, often generationally, knowledgeable of each other (e.g. the older generation knew when a youngster was born, knew their parents, grandparents etc.). Thus rural folk were ideally perceived to interact on the basis of biographised, interpersonal knowledge - that is, between named and known individuals - and accordingly experienced genuinely intimate family, neighbourly and community relationships.

Leaving aside the fact that rural families and communities are potentially as conflict-ridden as their metropolitan equivalents, the romanticisation of rural sociality clearly provided a counter to the unknowable strangers, the scripted, contractual and 'socially sterile' interactions, and the anonymity that many tourists experienced in various spheres of their everyday existence (e.g. in shopping malls, supermarkets, city streets). Therefore, as noted, when holidaying in Martinborough many tourists enthusiastically adopted what they perceived as ideal rural sociality and waved to passing strangers or wished them a 'cheery hello'. Furthermore, many sought to biographise their interactions with Martinborough's winemakers, homestay operators and retailers. Many thus actively sought winemakers' personal 'back stories' of how they developed an interest in wine, established vineyards in Martinborough, their wine preferences, future development plans and stories of their family/social life in Martinborough. Indeed, tourists often spontaneously introduced themselves to winemakers and offered similarly personalised narratives of their experiences of Martinborough wines, specific holiday motivations, distinct tastes in wine and other personal details such as their occupations and place of domestic residency.

Some cynically believed they received 'special service' from retailers/ producers if they established such 'friendly relations'. However, most were effectively attempting to transcend the contractual necessities (e.g. price, monetary exchange) and alienated character of commodity production and purchase. ${ }^{96}$ Tourists thus attempted to turn conventional acts of market exchange into gift-like transactions - that is, reciprocal exchanges between named individuals who intimately know each other - the type of exchange that some believed ideally characterises relationships in the rural idyll. Indeed, winemakers regularly received gifts from consumers, and some reported that they had commenced long-lasting friendships in this manner. Similarly, homestay operators reported that paying guests sent them thank-you cards, left gifts of wine and chocolates, or often wanted simply to 'sit and 
talk over breakfast'. Some tourists even offered freely to host the homestay operators should they visit their hometown. None of the homestay operators I encountered had, however, accepted such offers and thus had effectively rejected the social conviviality of the tourists' rural idyll: 'It just wouldn't feel right, after all at the end of the day they are paying to stay with us' (Homestay operator, female, late 50s).

Lifestyle magazines also regularly featured articles on Martinborough and other New Zealand winemakers that similarly biographised their winemaking endeavours. For example, a NZ House \& Garden article entitled 'The Finer Things' featured the self-proclaimed 'Ata Rangi four' (Clive and Phyll Paton, Oliver and Ali Masters) and detailed how the vineyard is dotted with personalised trees (e.g. wedding trees, trees planted to commemorate loved Granddads), noting that "Clive is as passionate about trees as he is about wine' ${ }^{97}$ The article featured photographs of the luxurious, cosmopolitan interiors of their respective domestic residences and noted that 'Phyll designed the olive motif on the specially made Morris \& James kitchen tiles, ${ }^{98}$

The biographisation of Martinborough winemakers and other vineyard personnel was also a prominent feature of vineyard websites. For example, the Ata Rangi website, which also contained photographs of the individuals referred to, clearly adulated their founder, Clive Paton, as a passionate visionary, purposeful artisan and distinct personality:

Clive had formerly been farming in the South Wairarapa but his love affair with red wine and belief in the potential of the area for grapegrowing led him to the Martinborough terrace and into Pinot Noir. Clive is right into fitness and sport, with mountain biking his current focus ... The conservation and extension of New Zealand's native forest is a real passion. Out of vintage (when not coaching the kids' soccer team) he spends as many weekends as he can cultivating and planting trees at the Bush Block.99

The celebrity adulation of Martinborough winemakers, in collusion with the biographisation of production, purchase and consumption, clearly served to dialogically assert the distinct personalities of winemakers and tourists alike. In biographising various moments of purchase or consumption, tourists were, in part, engineering performative opportunities to express their personal nexus of choice, taste and social capital - especially connectedness with renowned winemakers and with those with whom they shared bottles of wine. Likewise, the biographisation of winemakers transformed what could easily have been anonymous commodity production into an act of named artisanship. Thus the narratives of biographisation not only emphasised that the transacting winemakers and tourists were distinct, named entities, but also 
highlighted their autonomy, personal sensibilities, progressive inclinations and their personally formed social connectedness - in sum, their ideal reflexive individuality.

Martinborough's winemakers were routinely cast as consummate middleclass and ideal reflexive individuals. Winemakers were especially perceived of as autonomous, passionate, scientific/rational and progressively innovative in their New World winemaking endeavours, whose unique personalities, production philosophies and palates were determinative of wine quality and taste characteristics, and who led accomplished urbane lifestyles. Furthermore, Martinborough winemakers were characteristically lauded for producing an exceptionally urbane commodity in wine, for their refined tastes in domestic architecture, interior design etc., and for successfully achieving 'work-life balance'.

Indeed, it was not unusual to hear tourists verbally daydream about 'how nice it would be to own a vineyard' and, tellingly, how this would enable them to be 'their own boss', as well as producing something substantive or material (compared to the transience of 'paperwork'). Tourists also evocatively fantasised that operating a vineyard would enable them to drink and share their 'own wine' with friends. In these fantastical narratives tourists again emphasised their desire for autonomy, social recognition, reward and celebration of their productive efforts, in essence, for ideal reflexive individuality. Although in such instances, the enchanted, extra-ordinary lens of the metro-rural idyll was directed back toward an imaginary of their everyday employment, consumption and sociality.

\section{Conclusion}

Martinborough's wine tourists constructed and deployed a genealogical, vernacular rural idyll that essentially underscored and authenticated their metropolitan or everyday dispositions and orientations. The tourists thus constructed a metro-rural idyll - an enchanted or extra-ordinary, episodic and performative site - in which the leisured, conspicuous and idealised pursuit of middle-class distinction and reflexive individuality were especially prominent and readily maintained. In terms of their picturesque aesthetics and their adulation of rural artisanship, the tourists respectively pursued ephemeral, fashionable and urbane consumption of wine and celebrated the ideal reflexive individuality and middle-class distinction of celebrity winemakers. In many respects the tourists' metro-rural ideals and aspirations echo those of the Hon. John Martin, who founded Martinborough in the rurality of the Wairarapa as an embedded testament to his metropolitanbased successes in business, politics and high society. And like Martin's successes, the tourists' middle-class and reflexive ideals were couched as a 


\title{
mutually constitutive, negotiated mix of individual achievement and social confirmation.
}

\author{
Many thanks to Prof. Brigitte Bönisch-Brednich, Amanda Gilbertson, \\ Corinna Howland, Dr. Carolyn Morris and the anonymous reviewers for \\ their constructive comments and ruminations. Any errors or omissions \\ remain, of course, my responsibility.
}

1 Quotes not referenced to specific informants are records of utterances commonly expressed by a range of Martinborough tourists encountered during my fieldwork research.

2 P. Howland, 'Metro-rurality, social distinction and ideal reflexive individuality: Martinborough's Wine Tourists', PhD thesis, University of Canterbury, 2008, pp.18-21, 334-40. See also M. Abramovici, 'What is behind the romance of the grape? A case study of Wairarapa, New Zealand', MA thesis, Victoria University of Wellington, 2002.

3 Many Martinborough tourists can be classified as 'new middle class' (B. Roper, Prosperity for All?: Economic, Social and Political Change in New Zealand since 1935. Southbank, 2005, p.49). They are characteristically employed in white-collar jobs such as teaching, computer enterprises etc.; are tertiary educated or have technical qualifications; enjoy greater occupational autonomy, creativity, re-training opportunities and mobility and often greater affluence and improved life chances than most blue-collar workers. 'Middle class' was also a catch-all term used by tourists to describe a wide range of individuals - from the tertiary educated to artists, bureaucrats, teachers, winemakers, lawyers, doctors, C.E.Os, wealthy financiers and local estate farmers. The majority of tourists I encountered were essentially mid-range middle class and were (or at least appeared to be) dependent on small/medium-sized business or occupational incomes; tertiary educated; and ranged in wine experience from novices to knowledgeable, experienced drinkers. The numbers I met who were extremely affluent or genuine wine connoisseurs (other than wine makers or critics) was thus limited, and my analysis does not necessarily extend to them.

4 R. Williams, The Country and the City, London, 1973.

5 Reflexive individualism or self-referential/motivated personhood can be contrasted with partible personhood. Partible personhood is typical of kinship/ancestor-based societies and is essentially socio-centric. Thus an individual's social roles and status are determined by cultural ascriptions of kinship, gender, birth order etc. and via comparative relations with the partible personhood of contextually participant others (see M. Strathern, The Gender of the Gift, Berkeley, 1998, pp.192-207.). Reflexive individualism, however, is more characteristic of contemporary meritocratic societies and emphasises a selfassembled personhood that is pursued via autobiographic narrative, lifestyle choices, personalised identity affiliations etc. Reflexive individualism does not necessarily result in narcissistic tendencies, rather an individual's subjective beliefs, values, moralities and aspirations are celebrated as distinctly influential in guiding their social actions and interactions (see U. Beck, Individualization: Institutionalized Individualism and its Social and Political Consequences, London, 2002; A. Giddens, Modernity and Self-Identity: Self and Society in the Late Modern Age, London, 1991).

6 Howland, 'Metro-rurality', pp.87-131.

7 Ibid., pp.54-60.

8 R. Mclntyre, The Canoes of Kupe: A History of Martinborough District, Wellington, 2002, p.124.

9 www.swdc.govt.nz, November 2007. 
10 Dominion, 'Wine land goes for record sum', 22 April 2002, p.12.

11 NZ Wine Growers 2007, pp.7-15.

12 Statistics New Zealand, 1996.

13 Statistics New Zealand, 2004.

14 The Club Hotel was demolished during the 1970s and was replaced by the Pukemanu Tavern.

15 www.wairarapanz.com, April 2005.

16 www.stats.govt.nz, November 2007.

17 Howland, 'Metro-rurality', p.28.

18 Ibid., p.29.

19 E. Hobsbawm \& T. Ranger, 'Introduction: Inventing Traditions', in E. Hobsbawm \& T. Ranger, eds, The Invention of Tradition, Cambridge, 1996, p.1.

20 A. Appadurai, Modernity at Large: Cultural Dimensions of Globalization, Minneapolis, 1996, p.17.

21 A. Weiner, Inalienable Possessions: The Paradox of Keeping-While-Giving, Berkeley, 1992, p.4.

22 P. Howland, Lotro, Long-drops \& Lolly Scrambles: The Extra-Ordinary Anthropology of Middle New Zealand, Wellington, 2004, p.103.

23 For example, 73 or $47 \%$ of tourists responding to a survey $(n=156) \mid$ conducted stated they had dependent live-at-home children aged 16 years or younger, and of these $85 \%$ of males $(n=39)$ and $79 \%$ of females $(n=34)$ visited Martinborough without their children. Howland, 'Metro-rurality', pp.342-43. Abramovici conducted a similar survey $(n=120)$ at four Martinborough vineyards and reported comparable results, with $34 \%$ or 41 respondents stating they had children at home and nearly $80 \%$ or 32 of these touring without their children. Abramovici, p.60.

24 Wairarapa News, 'Red tape gone mad', 2 June 1999, p.5.

25 Howland, 'Metro-rurality', pp.115-16.

26 B. Ching \& G. Creed, Knowing Your Place: Rural identity and cultural hierarchy. New York, 1997, pp.19-20.

27 J. Urry, The Tourist Gaze, London, 1990.

28 G. Ritzer, Enchanting a Dis-enchanted World: Revolutionizing the Means of Consumption, Thousand Oaks, 2002.

29 J. Hillier \& E. Rooksby, eds, 'Introduction', in Habitus: A Sense of Place, Aldershot, 2002, pp.3-42.

30 Howland, 'Metro-rurality', pp.44-47, $118-23,166-79$.

31 P. Bourdieu, Distinction: A Social Critique of the Judgement of Taste, London, 1984, pp.55-56.

32 Bourdieu, p.12.

33 Howland, 'Metro-rurality', pp.13-14.

34 Howland, 'Metro-rurality', p.217.

35 Howland, Gifting the Self: The Metro-Rural Idyll and Ideal Reflexive Individuality, forthcoming.

36 Abramovici; Howland, 'Metro-rurality', pp.136-46.

37 Howland, Lotto, p.I10.

38 Beck, p.xxii.

39 Beck, pp.2-3.

40 Beck, p.5.

41 P. Sweetman, 'Twenty-first century dis-ease? Habitual reflexivity or the reflexive habits', Sociological Review, 51,4 (2003), p.537

42 P. Bourdieu, The Logic of Practice, Cambridge, 1990, p.53.

43 Bourdieu, Practical Reason: On the Theory of Action, 1998, p.8. 
44 Bourdieu, Distinction, p.101.

45 For example, the New Zealand Curriculum/Te Marautanga o Aotearoa, which is universal to all pre-tertiary schools, instils many of the attributes of reflexive individualism. 'Students will gain knowledge of: the values of the main cultural and institutional traditions of Aotearoa New Zealand and global society; their own values and the values of others; . . . will develop their ability to: express their own values; examine with empathy the values of others; . . . will be supported to value: Diversity . . . Ministry of Education, Curriculum Stocktake Report to Minister of Education, Wellington, 2002 (emphasis mine). These objectives essentially recognise that individuals are embedded in broad, highly differentiated social and cultural milieus, which require self-aware engagement, critical analysis and creative negotiation.

46 P. Bourdieu, Outline of a Theory of Practice, Cambridge, 1997, p.72.

47 A. Gilberston, 'Symbolic ethnicity and the dilemmas of difference: Talking Indianness with New Zealand-born Gujaratis', MA thesis. Victoria University of Wellington, 2007.

48 P. Nilan, 'The Reflexive Youth Culture of Devout Muslim Youth in Indonesia', in P. Nilan and C. Feixa, eds, Global Youth?: Hybrid identities, plural worlds, New York, 2006, pp.91-110.

49 Howland, 'Metro-rurality', p.53.

50 Beck; Giddens.

51 C. Campbell, The Romantic Ethic and the Spirit of Contemporary Consumerism, Oxford, 1987.

52 Z. Bauman, Liquid Modernity, Cambridge, 2000.

53 U. Beck, Risk Society: Towards a New Modernity, London, 1992.

54 See, for example, M. Douglas \& B. Isherwood, The World of Goods: Towards an Anthropology of Consumption, New York, 1996; G. McCracken, Culture and Consumption: New Approaches to the Symbolic Character of Consumer Goods and Activities, Bloomington, 1990; T. Veblen, The Theory of the Leisure Class: An Economic Study of Institutions, London, 1925.

55 A. Giddens, The Transformation of Intimacy: Sexuality, Love and Eroticism in Modern Societies, Cambridge, 1992. p.2.

56 Howland. 'Metro-rurality', p.iii.

57 Beck, Individualization; Giddens, The Transformation of Intimacy; R. Pahl \& L. Spencer, 'Personal Communities: Not Simply Families of "Fate" or "Choice"', Current Sociology, 52 (2004), pp.199-221; S. Rose \& S. Budgeon, 'Social Change in the Early 21 st Century', Current Sociology, 52 (2004), pp.135-59.

58 Beck, Individualization; Giddens, Modernity and Self-Identity; Gilbertson; Nilan: L. McNay, Gender and Agency: Reconfiguring the Subject in Feminist and Social Theory, Cambridge, 2000.

59 www.wairarapanz.com, November 2004; 2001-2002 Wairarapa Escape Planner, p.1 (emphasis in original).

60 www.wairarapanz.com, June 2005.

61 Toast Martinborough is an annual wine and food festival held in November since 1992. Participating vineyards team up with restaurants and musicians to provide on-site wine, food and entertainment for the day-long festival, which currently attracts about 10,000 visitors.

62 Bourdieu, Distinction; C. Campbell, 'The secret religion of the educated classes', Sociological Analysis, 39, 2 (1978), pp.146-56.

63 This reference is evident in a popular Martinborough café that is named after the Medici family, a renowned fourteenth- and fifteenth-century ltalian noble family who are widely credited with initiating the European Renaissance through their patronage of artists. 
Café Medici features a forte piano decorated in Baroque style and Renaissance-styled landscape wall hangings painted by the owner, and well-known New Zealand artist, Stephen Allwood.

64 D. Cosgrove, Social Formation and Symbolic Landscape, Wisconsin, 1998.

65 S. Schama, Landscape and Memory, London, 1996, p.540.

66 L. Withey, Grand Tours and Cook's Tours: A History of Leisure Travel, 1750-1915, New York, 1997, p.48.

67 The Claude-glass is a small convex mirror mounted on a piece of black felt and is named after the master French landscape painter Claude Lorrain (1600-1682). To use a Claude-glass, one faced away from the view to catch the reflection of the scene, a technique that supposedly sharpened the image and softened the colours.

68 Schama; Withey.

69 Bourdieu, Distincrion; Urry.

70 J. McAloon, No Idle Rich: The Wealthy in Canterbury and Otago, 1840-1914, Dunedin, 2002.

71 J. Belich, Making Peoples: A History of the New Zealanders, Auckland, 1996, p.299.

72 Belich, p.300.

73 Belich, p.302.

74 Schama.

75 www.foodstandards.gov.au, August 2006. .

76 Arnaud de Pontac, the first president of the Bordeaux regional parliament, established the custom of naming individual vineyards and also created chateau-specific wines when in 1660 he sold the first Bordeaux wine, Haut-Brion, under the name of the estate where it was produced. H. Johnson, Story of Wine, London, 1998, p.202.

77 In 1666, Arnaud de Pontac opened possibly London's first restaurant, the Pontack's Head, just behind the Old Bailey. Its prices were extremely high, Haut-Brion sold for seven shillings a bottle, compared with the standard two shillings for a good wine. Pontack's Head remained in business until 1780 when it was demolished. Johnson, p.203.

78 M. Demossier, "Consuming Wine in France: The "Wandering" Drinker and the Vin-anomie', in T. Wilson, ed., Drinking Cultures, Oxford, 2005, p.131.

79 Appadurai, p.83; see also McCracken, pp.18-20.

80 Appadurai, p.84.

81 lbid., p.77.

82 Ibid.

83 Beck, Individualization; Giddens, Modernity and Self-Identity.

84 E. Gellner, Nations and Nationalism, New York, 1983.

85 M. Demossier, p.132.

86 Howland, 'Metro-rurality', pp.261-63.

87 Appadurai, p.77.

88 M. Crang, 'Picturing Practices: research through the Tourist gaze', Progress in Human Geography, 21, 3 (1997), p.366.

89 Rough translation: 'in the dark room', although it is probably also a play on the notion of noir re: Pinot Noir (the dark grape or food).

90 Howland, Lotto, pp.103-11.

91 Dominion, 'Well Red', 1999, March 20, p.19 (emphasis mine). Larry McKenna was the winemaker at Martinborough Vineyard.

92 Dominion, 'The man from Dry River', 2000, January 14, p.ll (emphasis mine). Dr McCallum was the owner and winemaker of Dry River vineyard.

93 Howland, 'Metro-rurality', p.198.

94 Terroir basically refers to geographical provenance or the influence of soil types, rainfall and climate. 
Journal of New Zealand Studies

95 J. Robinson, ed., The Oxford Companion to Wine, Oxford, 1999, p.488 (emphasis in original).

96 J. Carrier, 'Reconciling commodities and personal relations in industrial society', Theory and Sociery, 19 (1990), pp.579-98.

97 New Zealand House \& Garden, 'The Finer Things', July, 47, 1998, p.130.

98 Ibid, p.125.

99 www.atarangi.co.nz, November 2006 (emphasis in original). 